\title{
A research on application of water treatment technology for reclaimed water irrigation
}

\author{
Meng Xu ${ }^{a, b}$, Xiao Bai ${ }^{c, *}$, Liang Pei ${ }^{d}$, Hulin Pan ${ }^{b}$ \\ a Ministry of Education Key Lab of Water and Sand Science, School of Environment, Beijing Normal University, \\ Beijing 100875, China \\ b School of Public Administration, Zhejiang University of Finance and Economics, Hangzhou 310018, China \\ c School of Finance, Zhejiang University of Finance \& Economics, Hangzhou 310018, China \\ ${ }^{\mathrm{d}}$ Key Laboratory of Water Cycle and Related Land Surface Processes, Institute of Geographic Sciences and Natural \\ Resources Research, Chinese Academy of Sciences, Beijing 100101, China
}

\section{A R T I C L E I N F O}

Article history:

Received 30 March 2016

Accepted 4 May 2016

Available online 20 June 2016

Keywords:

Reclaimed water irrigation

Water quality standards

Water treatment technology

Membrane bio-reactor

Management requirement

\begin{abstract}
A B S T R A C T
Water, taken as the source of life, is one of the most important constituent parts of the global ecological system. The water resources problem is becoming more and more severe as a result of the acceleration of the process of urbanization in China and an increased population since reform and opening up. Therefore, reclaimed water irrigation is one of the effective measures to deal with the scarcity of water resources. In line with the necessity and urgency of reclaimed water reuse at present, brief analyses are made on the determination of both the reclaimed water treatment and the relevant irrigation technology, and then explanations and studies are made from such perspectives as the construction purpose, the water quality standards and the technological process. Finally the relevant new technologies and technical requirements for the reclaimed water treatment are put forward for the reclaimed water irrigation from such aspects as the techniques and technologies related to sewage treatment, the technical requirements and standards for reclaimed water irrigation, and the management and monitoring of reclaimed water irrigation.
\end{abstract}

@ 2016 Hydrogen Energy Publications LLC. Published by Elsevier Ltd. All rights reserved.

\section{Introduction}

Water, taken as the source of life, is one of the most important constituent parts of the global ecological system. The water resources problem is becoming more and more severe as a result of the accelerated process of urbanization in China, industrial and agricultural development and an increased population since reform and opening up. China would begin to enter into a period of severe water scarcity since 2010, with the water resources situation being especially severe in the northern region, according to a survey in Water Supply And Demand in China in the 21st Century from the Ministry of Water Resources. Therefore, it is extremely urgent to alleviate the water scarcity by strengthening studies on water recycling while improving efficiency in water utilization [1-3].

Recycling reclaimed water is one of the effective ways to reduce sources of pollution and solve the issue of water scarcity, and irrigation is one of the important measures to recycle the reclaimed water. As an effective method of saving

\footnotetext{
* Corresponding author.

E-mail address: baixiao@zufe.edu.cn (X. Bai). 
water resources, reclaimed water has been widely adopted by developed countries to irrigate farms in lieu of drinking water. The traditional irrigation mode not only causes huge waste of water resources, but is unable to meet the irrigation requirements, as agricultural crops have various varieties, and different requirements for irrigation water volumes, locations, irrigating methods. Therefore, it is of paramount importance to explore the technologies and modes of reclaimed water irrigation on farm [4,5]. It would be best to adopt a combination of technologies for disposal and reuse of domestic wastewater as well as for irrigation with respect to reclaimed water irrigation in order to achieve the purposes of transforming the sewage into resources and improving water utilization ratio and labor productivity while saving water. The effluent from the sewage treatment device for irrigation application features stable and reliable volume and quality, which is not only capable of reducing discharge of pollutants and relieving shortage of water resources, but can even be used as a reliable alternative source of water and fertilizer. Thus, study of technological mode for treatment of reclaimed water, recycling of reclaimed water in farm irrigation, as well as nationwide development and promotion will be of great strategic significance $[6,7]$.

\section{Water quality standards of reclaimed water irrigation}

In china, water shall be divided into water for agriculture, forestry, animal husbandry and fishery industry, water for urban miscellaneous use, industrial water, water for environment and water for supplementing source of water according to the purposes of wastewater treatment and reuse in The Reuse of Urban Recycling Water-Classified Standard (GB/T 18919-2002). At present, there are uniform national standards with respect to each of farm irrigation, urban miscellaneous use, industrial water, water for environment and groundwater recharge $[8,9]$.

\section{Water quality standards of reclaimed water irrigation for urban green land}

Limits for the physiochemical indexes and hygienic indexes of the reclaimed water for irrigation of urban green land shall conform to the provisions in Table 1.

Table 1 - Water quality standards of reclaimed water for irrigation of urban green land.

\begin{tabular}{lll} 
& \multicolumn{1}{c}{ Index } & Limit \\
\hline 1 & $\mathrm{BOD}_{5} /(\mathrm{mg} / \mathrm{L})$ & $\leq 20$ \\
2 & $\mathrm{COD}_{\mathrm{Cr}} /(\mathrm{mg} / \mathrm{L})$ & $\leq 100$ \\
3 & $\mathrm{SS} /(\mathrm{mg} / \mathrm{L})$ & $\leq 30$ \\
4 & $\mathrm{LAS} /(\mathrm{mg} / \mathrm{L})$ & $\leq 1$ \\
5 & $\mathrm{Fecal} \mathrm{coliform} /(\mathrm{MPN} / 100 \mathrm{~mL})$ & $\leq 200$ \\
6 & $\mathrm{TN} /(\mathrm{mg} / \mathrm{L})$ & $\leq 30$ \\
7 & $\mathrm{TP} /(\mathrm{mg} / \mathrm{L})$ & $\leq 30$ \\
8 & $\mathrm{Total} \mathrm{residual}$ nitrogen/(mg/L) & $\leq 2$ \\
9 & $\mathrm{pH}$ & $6-9$ \\
\hline
\end{tabular}

Water quality standards of agricultural reclaimed water irrigation

The basic control items of quality of reclaimed water for agricultural irrigation are shown in Table 2.

\section{Reclaimed water treatment and irrigation technologies}

\section{Introduction to treatment method of water for reclaimed water irrigation}

The optimization and grouping shall be implemented by selecting rational treatment technology units according to properties and characteristics of sewage, purpose of water recycled, physiographic conditions, project investment, operation costs, because a certain single water treatment process is difficult to meet the requirement for quality of water recycled. At present, the urban sewage treatment process in China mainly includes such conventional processes as coagulation, sedimentation, filtering, sterilization and so on; there are also many other methods for advanced treatment, including coagulation and clarifying filtration, absorptive filtering with activated carbons, ultrafiltration, semipermeable membrane, ionic exchange, reverse osmosis, biological method, micro-flocculation, contact mechanism of oxidation and filtration, ozonation, etc $[10,11]$. See Table 3 for corresponding treatment method. Moreover, the requirements for the quality of agricultural irrigation water continue to be improved, and further requirements are being put forward from more aspects including color, turbidity, pathogenic bacteria, etc. along with the progress in water treatment technologies and social development.

\section{Application and study of MBR in reclaimed water irrigation}

In recent years, the MBR has been applied to sewage reclamation and reuse on a wider and wider scale, and has brought about obvious economical benefits, considerable environmental benefits and social benefits [12-14].

The research group has established relevant test base and demonstration village in Yingzi Village, Saiwudang Administration, Maojian District, Shiyan, Hubei Province, wherein the design scale of the recycling project of reclaimed water is $5 \mathrm{~m}^{3} / \mathrm{d}$; and the raw water refers to rural domestic sewage. Twater quality of the same is shown in Table 4.

The sewage treatment system adopts the combined process system in which full-automatic membrane bio-reactor (MBR) is combined with the advanced oxidation process (AOP). Moreover, the procedure of the sewage treatment process is as follows: domestic sewage-pretreatment tank-anaerobic/aerobic membrane tank-reclaimed water (Fig. 1).

The combined process in which the membrane bio-reactor (MBR) is combined with the advanced oxidation process (AOP) may be implemented for treatment of sewage of any quality $[15,16]$. The MBR treatment process has the advantages of both the membrane separation technique and the bio-treatment technology; and the all-in-one MBR reactor integrates 
Table 2 - Basic control items of quality of reclaimed water for agricultural irrigation.

\begin{tabular}{|c|c|c|c|c|c|}
\hline \multicolumn{2}{|r|}{ Index } & \multicolumn{4}{|c|}{ Types of crops to be irrigated } \\
\hline & & $\begin{array}{l}\text { Grain and oil } \\
\text { crops in dry land }\end{array}$ & $\begin{array}{c}\text { Textile } \\
\text { crop }\end{array}$ & $\begin{array}{c}\text { Outdoor } \\
\text { vegetable }\end{array}$ & $\begin{array}{l}\text { Grain in } \\
\text { paddy field }\end{array}$ \\
\hline 1 & $\mathrm{BOD}_{5} /(\mathrm{mg} / \mathrm{L})$ & 80 & 100 & 40 & 60 \\
\hline 2 & $\mathrm{COD}_{\mathrm{Cr}} /(\mathrm{mg} / \mathrm{L})$ & 180 & 200 & 100 & 150 \\
\hline 3 & $\mathrm{SS} /(\mathrm{mg} / \mathrm{L})$ & 90 & 100 & 60 & 80 \\
\hline 4 & $\mathrm{DO} /(\mathrm{mg} / \mathrm{L})$ & - & & $\geq 0.5$ & \\
\hline 5 & Fecal coliform/(10 $0^{4}$ pieces/L) & 4 & & & \\
\hline 6 & Total dissolved solids/(mg/L) & $\begin{array}{l}1000 \text { in regio } \\
2000 \text { in regio }\end{array}$ & $\begin{array}{l}\text { ssaline-all } \\
\text { ne-alkali }\end{array}$ & & \\
\hline 7 & Residual chlorine/(mg/L) & 2 & & 1 & \\
\hline 8 & Number of ascaris eggs/(piece/L) & 2 & & & \\
\hline 9 & $\mathrm{pH}$ & $6-9$ & & & \\
\hline
\end{tabular}

Table 3 - Treatment method of water for reclaimed water for agricultural irrigation.

\begin{tabular}{|c|c|c|}
\hline Pollutant & & Treatment method \\
\hline \multirow[t]{2}{*}{ Nutrient } & Nitrogen & $\begin{array}{l}\text { Biological nitrification, denitrification, ammonia stripping, ionic } \\
\text { exchange, etc. }\end{array}$ \\
\hline & Phosphorus & Biological phosphorus removal, coagulation, sedimentation and filtering. \\
\hline Inorganic salt & Solubility & $\begin{array}{l}\text { Ultrafiltration, reverse osmosis, electrodialysis, ionic exchange, } \\
\text { distillation and cooling. }\end{array}$ \\
\hline \multirow[t]{2}{*}{ Organic matter } & Solubility & $\begin{array}{l}\text { Ozonation, coagulating sedimentation, activated carbon adsorption and } \\
\text { biochemical treatment. }\end{array}$ \\
\hline & Suspension property & $\begin{array}{l}\text { Coagulating sedimentation, microfiltration, ultrafiltration, reverse } \\
\text { osmosis, air floatation, etc. }\end{array}$ \\
\hline
\end{tabular}

membrane separation, bio-reaction, aerobiotic process and aeration, featuring compact volume, rational structure, less land occupation; therefore the decomposition and oxidation rate by organism of organic matter, as well as the removal rate of inorganic matters such as nitrogen and phosphorus are greatly improved. Moreover, the water filtrated by the ultrafiltration membrane has super high quality, and the system hardly discharges any residual sludge.

The AOP advanced oxidation process activates molecules from the MBR effluent through photoelectric chemical reaction and generates oxidant. $\mathrm{OH}$ (hydroxyl radical) with extremely strong oxidizability and capability of rapidly degrading all poisonous and harmful difficult-to-oxidize matters in water so that TOC in water will finally be zero. Further the hydroxyl radical has the functions of decolorization and deodoraization, as well as a strong sterilization function, therefore delivering effluent of higher water quality. According to test results, the quality of water after being processed by MBR + AOP can reach the latest standard of

Table 4 - Water quality condition of rural domestic sewage.

\begin{tabular}{lll} 
& \multicolumn{1}{c}{ Index } & \multicolumn{1}{c}{ Value } \\
\hline 1 & $\mathrm{COD}_{\mathrm{Cr}}\left(\mathrm{mg} \mathrm{L}^{-1}\right)$ & $50-300$ \\
2 & $\mathrm{NH}_{3}-\mathrm{N}\left(\mathrm{mg} \mathrm{L}^{-1}\right)$ & $10-60$ \\
3 & Turbidity (NTU) & $30-250$ \\
4 & $\mathrm{SS}\left(\mathrm{mg} \mathrm{L}^{-1}\right)$ & $100-300$ \\
5 & $\mathrm{Temperature} /{ }^{\circ} \mathrm{C}$ & $10-40$ \\
6 & $\mathrm{pH}$ & $6-9$ \\
\hline
\end{tabular}

domestic drinking water issued by the State. The intermittent aeration system of the regulating tank forms excellent anoxic and anaerobic conditions and accelerates the nitrification and denitrification processes [17]. The sludge returning system of the membrane tank is conducive to the regulation of microorganism concentration in the membrane tank and the maintenance of the activity of the microorganism. The advanced program design of the PIC automatic control system ensures that the system can run automatically and normally for a long time, while achieving the purposes of saving energy and reducing consumption. Moreover, no additional flocculant or advanced oxidation disinfectant is required due to the low operating costs and the presence of the AOP system.

Major performance indexes of the technology:

(1) Influent mainly refers to urban and rural domestic sewage or industrial wastewater (Tables 1-5) of similar quality, wherein the quality of the effluent can be made superior to the Class-A sewage discharge standard stipulated by the State by adjusting appropriate parameters; and the water may also be recycled for various purposes by adjusting parameters according to needs so as to meet higher recycling requirements.

(2) The total power of the equipment shall be $0.24 \mathrm{KW}$; the cost for treating each ton of water shall be RMB0.25.

(3) The buried design pattern shall be adopted, with less land being occupied $\varnothing 1.2 \mathrm{~m} \times 1.8 \mathrm{~m}$ high.

(4) The full automatic control technology can realize unattended operation; and the quality of the effluent may be adjusted according to the requirements of the users. 


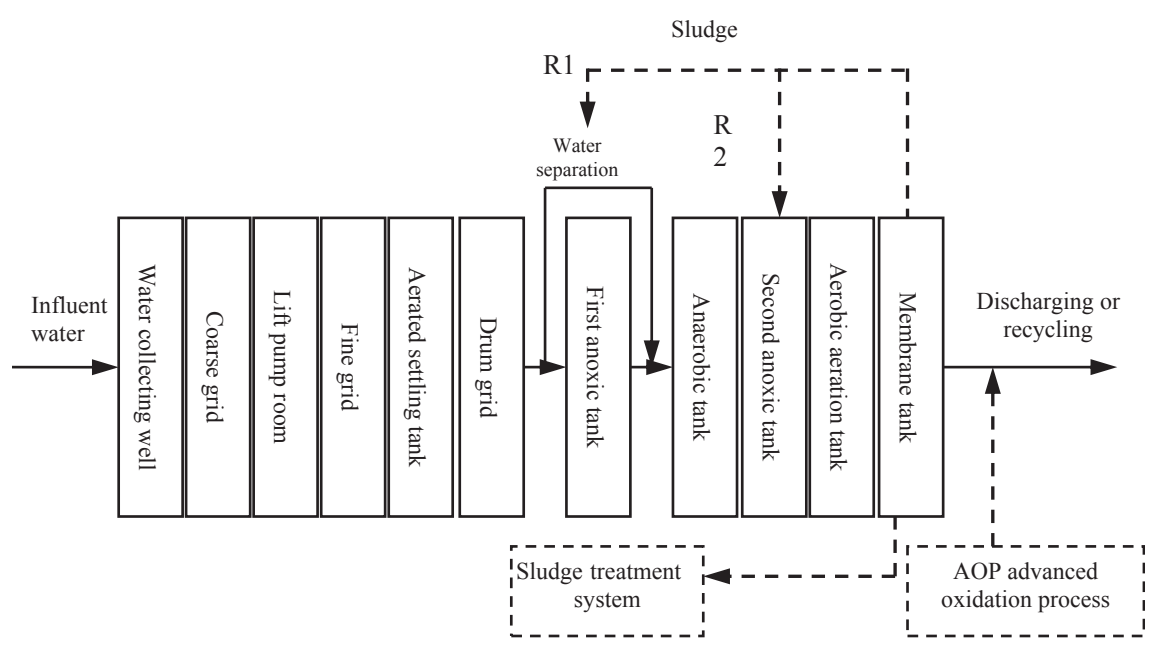

Fig. 1 - Technique flow chart.

\section{Drop irrigation and recycling technologies of reclaimed water}

The quality of the effluent from the rural domestic sewage processed using "Membrane Bioreactor + High-efficiency Oxidation Disinfection" treatment technology is superior to that of the Class-A sewage discharge standard (Table 5) stipulated by the State [18,19], and the effluent may also be applied to farm irrigation after achieving the standard (Table 3) of the agricultural irrigation water by adjusting aeration time and other parameters.

The technology was researched and developed in an allusion to the need of recycling and high-efficiency utilization of domestic sewage in water source area. The technical device and principle are shown in Figs. 2 and 3, which mainly include the sewage treatment system combining full-automatic MBR (membrane bioreactor) and AOP advanced oxidation process, precise fertilization and irrigation technologies by means of drop irrigation, etc. The main contents are as follows:

(1) MBR treatment process integrates advantages of membrane separation technology and bio-treatment technology, and therefore the decomposition rate and oxidation rate of organism to organic matter, as well as removal rate of inorganic matters, such as nitrogen and phosphorus will be greatly improved.

(2) Molecules in the MBR effluent will be activated through photoelectric chemical reaction to generate oxidant . OH (hydroxyl radical) with extremely strong oxidizability and capability of rapidly degrading poisonous and harmful matters that are difficult to oxidize in water so that TOC in water is finally zero; therefore, the decolorization, odor removal and sterilization are achieved.

(3) The domestic sewage will be collected by pipelines and sent to the reclaimed water reservoir after being centralized processed using the MBR + AOP filter system to serve as one of water sources of precise fertilization and irrigation technologies by means of drop irrigation combined dispatching of multiple water sources between the reclaimed water and surface water.

(4) The variable-frequency control submersible pump installed in the reclaimed water reservoir will be started automatically when the reclaimed water can meet the need of irrigation, while the valve installed in original surface water pipeline will be started to supplement the reclaimed water reservoir and implement synchronous irrigation by combining reclaimed water with the surface water during irrigation peak when the reclaimed water cannot meet the need of irrigation.

Technical effect: The water after treatment from domestic sewage will be directly applied to agricultural irrigation as liquid fertilizer for precise fertilization and irrigation technologies by means of drop irrigation, with the emission rate to the water body being 0; at the same time, the water after treatment can reduce application rate of chemical fertilizer, with effects of improving quality of crops and saving labors while protecting environment, saving fertilizer, and increasing yield.

Table 5 - Highest index attainable for quality of effluent after treatment.

\begin{tabular}{|c|c|c|c|c|c|c|}
\hline & \multicolumn{6}{|c|}{ Major water quality indexes $(\mathrm{mg} / \mathrm{L})$ of effluent } \\
\hline & $\begin{array}{l}\text { COD } \\
\text { COD }\end{array}$ & $\begin{array}{l}\mathrm{BOD}_{5} \\
\mathrm{BOD}_{5}\end{array}$ & Ammonia nitrogen & Total phosphorus & Total nitrogen & $\begin{array}{l}\text { SS } \\
\text { SS }\end{array}$ \\
\hline Class-A stipulated by the state & 50 & 10 & 5 & 0.5 & 15 & 10 \\
\hline MBR-AOP & 15 & 5 & 0.15 & 0.3 & 5 & 0 \\
\hline
\end{tabular}




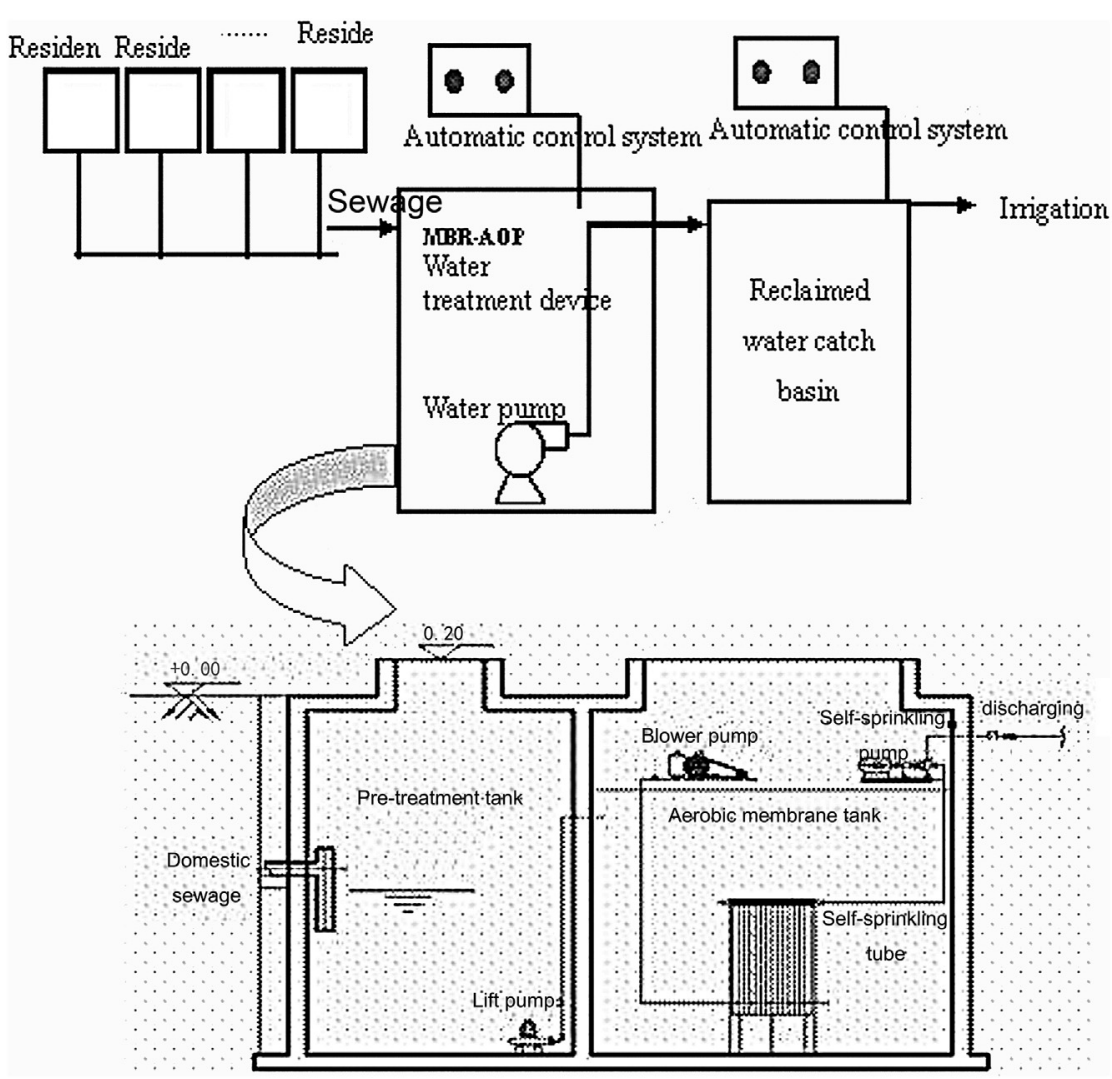

Fig. 2 - Procedures and water treatment device for high-efficiency utilizing technology of reclaimed water drop irrigation.

\section{Technical requirement for reclaimed water irrigation}

Whether the reclaimed water irrigation technology can be successfully popularized and applied depends not only on technological requirements for the design of the sewage treatment system, but on other aspects, such as water distribution and water supply in reclaimed water reuse, irrigation system, management and monitoring technologies, etc.

\section{Selection of appropriate irrigation method}

The reclaimed water irrigation should adopt the irrigation method and facilitates for high-efficiency water resource utilization, such as sprinkling irrigation, drop irrigation, etc. from the perspectives of modern agriculture and sustainable development of water resources; while the sprinkling irrigation and the drop irrigation should also be adopted from the perspective of pollution control in order to control agricultural non-point source pollution and control leaching of nutrients along with water into the runoff.

\section{Calculation of all kinds of balances}

The calculation of volume of irrigation water is especially important both in reclaimed water irrigation and clean-water irrigation, wherein the two irrigation methods are quite different from each other, as evidenced by the existence of certain amounts of nutrients, such as BOD, nitrogen, phosphorus, potassium, etc. in the reclaimed water which are beneficial for plants. Therefore, the calculation of balanced contents of water, nutrient, salt, oxygen and heavy metal shall be the key to successful reclaimed water irrigation.

(1) Water balance: Season and climate changes, properties, water-holding capacity and penetration coefficient of soil, as well as underground water level and distribution condition of the underground water, etc. are key factors which will affect the calculation and shall be given due consideration before calculation. The plant root system

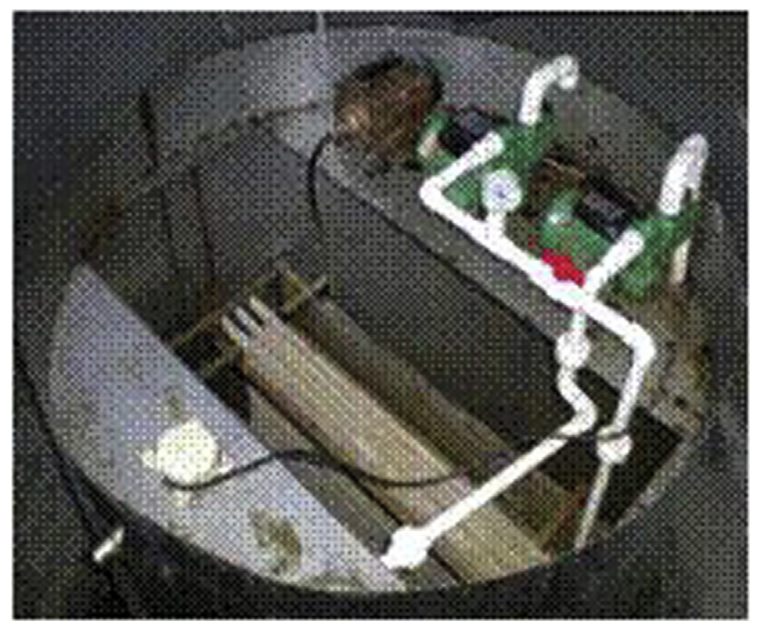

Fig. 3 - Photograph of device for high-efficiency. 
absorbs water and nutrients in the soil, and the transpiration of plant also causes partial loss of water, meanwhile the pull force generated by the transpiration also redistributes the water and nutrients in the plant. Moreover, the water volume as a result of precipitation must be taken into account as well when calculating water balance.

The calculation of water balance can be simply expressed as $\mathrm{Xh}=$ (precipitation + design flow rate of irrigation)-(total loss as result of water transpiration + diffusion loss) [20].

(2) Salt balance: The salt content should be lower than the limit that the crops can bear because different crops have different salt tolerances; otherwise, poisons may accumulate at root of the crop and affect growth. Moreover, the soil will become fertile and fluffy when there is appropriate amount of salt in the soil.

(3) Nutrient balance: The balance calculation of nutrients mainly includes the balance calculation of nitrogen, phosphorus, potassium and other elements which can be absorbed and utilized by the plant as nutrients in the soil. In the first place, the total amount of effective nutrients entering into the acreage of land through the reclaimed water irrigation, including the total load of nutrients in water, organic matter and fertilizer in the soil, and the residual nutrients in the crops.

(4) Oxygen balance: A knowledge of the texture, structure and reoxygenation ability of the soil will be the key to the calculation of oxygen balance. The temperatures of different soils will greatly affect the microbial activity and reoxygenation ability of the soil [21-23]. The common organic matter (COD) is located at the upper layer of the soil, and the microorganisms in the soil are very active during intermittent period of irrigation, and therefore the soil has obvious degradation and strong reoxygenation ability of soil. Thus, the irrigation load should be controlled to prevent the reoxygenation of the soil from being influenced as a result of an excessive soil tolerance.

(5) Heavy metal: The heavy metal may damage the activity of the soil and microorganisms, and also enter the food chain after being absorbed by the crops, thereby forming accumulative poison which is harmful to human health; and therefore, it is necessary to strictly control content of heavy metal. The reclaimed water irrigation should be implemented by selecting appropriate water source first $[4,24,25]$. Rural domestic sewage basically comprises no heavy metal and is suitable for reclaimed water irrigation; the heavy metal must be removed in the link of reclaimed water treatment system if industrial wastewater is adopted for the source water, or the useful heavy metal may also be separated and recycled by novel processes.

\section{Management and monitoring measures}

A complete automatic monitoring system will be required first for scientific management of reclaimed water treatment and irrigation system; and the accuracy and reliability and universality of the data should be ensured in time and space by observing and recording data through computer remote control [26,27]. Detailed management plans and rules for reclaimed water irrigation system and ancillary preferential policy on reclaimed water utilization will be formulated under the guidance of government; further, the management and monitoring efficiency of the reclaimed water irrigation system should be continuously improved. The main target of monitoring reclaimed water irrigation should be to monitor the crops, soil and the underground water. Information on nutrient balance and crops health can be known by monitoring crops irrigated with reclaimed water. The monitoring indexes mainly includes TKN, P, K, S, B, Zn and $\mathrm{H}_{2} \mathrm{O}$; the health status of the crops may be diagnosed and evaluated by monitoring indexes such as $\mathrm{Cu}, \mathrm{Mn}, \mathrm{Fe}, \mathrm{Mo}$, etc.; and the indexes, such as $\mathrm{Ca}, \mathrm{Mg}, \mathrm{Na}, \mathrm{Cl}$, etc. monitored will be applied to know the situation of salt absorption. The monitoring of salt includes conventional monitoring (monitoring of the soil sample at fixed time and place), and the monitoring contents includes $\mathrm{pH}, \mathrm{NO}_{3}-\mathrm{N}, \mathrm{CEC}$ and $\mathrm{H}_{2} \mathrm{O}$. Quarterly monitoring involves monitoring and evaluation of TKN, SAR, Cu, Mn and Fe; and the yearly evaluation of soil fertility is to make a comprehensive comparison and evaluation of the elements, such as organic matters, $\mathrm{NO}_{3}, \mathrm{NH}+4$, $\mathrm{P}, \mathrm{K}, \mathrm{SO}_{4}^{-}, \mathrm{S}, \mathrm{Ca}, \mathrm{Mg}, \mathrm{Na}$, etc. in the soil. Moreover, the monitoring of underground water includes monitoring of indexes, such as $\mathrm{EC}, \mathrm{pH}, \mathrm{NO}_{3}-\mathrm{N}$, T P, etc., aimed to inspect the abilities of soil and plant to absorb nitrogen and phosphorus in the reclaimed water and their effect to the underground water.

\section{Conclusion and prospect}

Relative shortage of water resource in China determines the practical choice of reclaimed water irrigation, which has obvious advantages as well as risks that must be prevented. The economical benefit should be carried out while avoiding environmental damage by adopting scientific and systematic policy, method and technical measures that can be used to draw on advantages and avoid disadvantages. The reclaimed water irrigation should be adjusted according to local conditions and planned rationally; the sewage should be treated effectively before irrigation; the standardized management of the reclaimed water irrigation should be strengthened; and the scientific research [22] of reclaimed water irrigation should be deeply implemented. Plenty of research work in the technical field of reclaimed water irrigation has been implemented at home and abroad, while the research on reclaimed water irrigation in China is still at its preliminary stage; therefore the following items shall be the directions of agricultural application and research of reclaimed water irrigation in China in an allusion to China's actual conditions: (1) study on the new treatment process of reclaimed water, new technology and system of reclaimed water irrigation; (2) formulate standards for reclaimed water irrigation; (3) rule of transportation and conversion of nitrogen, phosphorus, organic matter, and heavy metal in soil and vegetation system under the condition of reclaimed water irrigation; (4) safety and high-efficiency irrigation technology of reclaimed water, 
coupling and yield-increasing effect of reclaimed water irrigation and fertilization, and irrigation and fertilization amount suitable for the farm after reclaimed water irrigation; and (5) research and set up evaluation index and method of environment implications of reclaimed water irrigation and health risk.

Finally, to implement and popularize the application of reclaimed water irrigation will be a complicated systematic project, which involves many units and organizations, such as urban planning, construction, environmental protection, municipal administration, water conservancy, agriculture, etc., and the troubles in coordination and management are self-evident. Therefore, it is necessary to make a wide range of survey and research, establish a complete management system of reclaimed water irrigation while specifying the administrative power and water right. Moreover, the government should strengthen the concept of sewage reutilization, implement unified allocation and use in irrigation area with reclaimed water by bringing the reclaimed water into the integrated planning of water resources utilization while gaining a thorough understanding the position of reclaimed water irrigation in water resource allocation.

\section{Acknowledgment}

The paper is funded by Zhejiang province Funds for Distinguished Young Scientists (Grant No.: LR15E090002), the National Natural Science Foundation of China (Grant No.: $51379219,41371526)$ and the National Social Science Foundation of China (Grant No: 14BGL205).

\section{R E F E R E N C E S}

[1] Pedro-Monzonís María, Solera Abel, Ferrer Javier, Estrela Teodoro, Paredes-Arquiola Javier. A review of water scarcity and drought indexes in water resources planning and management. J Hydrology 2015;527(8):482-93.

[2] Hess TM, Lennard AT, Daccache A. Comparing local and global water scarcity information in determining the water scarcity footprint of potato cultivation in Great Britain. J Clean Prod 2015;87(15):666-74.

[3] Cao Xinchun, Wang Yubao, Wu Pute, Zhao Xining, Wang Juan. An evaluation of the water utilization and grain production of irrigated and rain-fed croplands in China. Sci Total Environ 2015;529(10):10-20.

[4] Lu Shibao, Pei Liang, Bai Xiao. Study on method of domestic wastewater treatment through new-type multi-layer artificial wetland. Int J Hydrogen Energy 2015;40(34):11207-14.

[5] Al Khamisi Saif A, Prathapar SA, Ahmed M. Conjunctive use of reclaimed water and groundwater in crop rotations. Agric Water Manag 2013;116(1):228-34.

[6] Furumai Hiroaki. Rainwater and reclaimed wastewater for sustainable urban water use. Phys Chem Earth, Parts A/B/C 2008;33(5):340-6.
[7] Lu S, Wang J, Pei L. Study on the effects of irrigation with reclaimed water on the content and distribution of heavy metals in soil. Int J Environ Res Public Health 2016;13:298

[8] Gaydon DS, Meinke H, Rodriguez D. The best farm-level irrigation strategy changes seasonally with fluctuating water availability. Agric Water Manag 2012;10(1):33-42.

[9] Darouich Hanaa, Gonçalves José M, Muga André, Pereira Luis S. Water saving vs. farm economics in cotton surface irrigation: an application of multicriteria analysis. Agric Water Manag 2012;115(12):223-31.

[10] Mouri Goro, Takizawa Satoshi, Fukushi Kensuke, Oki Taikan. Estimation of the effects of chemically-enhanced treatment of urban sewage system based on life-cycle management. Sustain Cities Soc 2013;9(12):23-31.

[11] Sidhu JPS, Ahmed W, Gernjak W, Aryal R, McCarthy D, Palmer A, et al. Sewage pollution in urban stormwater runoff as evident from the widespread presence of multiple microbial and chemical source tracking markers. Sci Total Environ 2013;463-464(1):488-96.

[12] Hooper Tara, Cooper Philip, Hunt Alistair, Austen Melanie. A methodology for the assessment of local-scale changes in marine environmental benefits and its application. Ecosyst Serv 2014;8(6):65-74.

[13] Barbose Galen, Bird Lori, Heeter Jenny, FloresEspino Francisco, Wiser Ryan. Costs and benefits of renewables portfolio standards in the United States. Renew Sustain Energy Rev 2015;52(12):523-33.

[14] Luz Martín-Peña María, Díaz-Garrido Eloísa, SánchezLópez José María. Analysis of benefits and difficulties associated with firms' Environmental Management Systems: the case of the Spanish automotive industry. J Clean Prod 2014;70(1):220-30.

[15] Hedayati Ali, Le Corre Olivier, Lacarrière Bruno, Llorca Jordi. Exergetic study of catalytic steam reforming of bio-ethanol over $\mathrm{Pd}-\mathrm{Rh} / \mathrm{CeO}_{2}$ with hydrogen purification in amembrane reactor. Int J Hydrogen Energy 2015;40(8):3574-81.

[16] Karataș Serdar, Hasar Halil, Tașkan Ergin, Özkaya Bestamin, Şahinkaya Erkan. Bio-reduction of tetrachloroethen using a $\mathrm{H}_{2}$-based membrane biofilm reactor and community fingerprinting. Water Res 2014;8(1):21-8.

[17] Su Yinglong, Zheng Xiong, Chen Aihui, Chen Yinguang, He Guangyu, Chen Haiqun. Hydroxyl functionalization of single-walled carbon nanotubes causes inhibition to the bacterial denitrificationprocess. Chem Eng J 1 November 2015;279:47-55.

[18] Muhid Priyanesh, Davis Timothy W, Bunn Stuart E, Burford Michele A. Effects of inorganic nutrients in recycled water on freshwater phytoplankton biomass and composition. Water Res 2013;47(1):384-94.

[19] Ahmad Mutamim Noor Sabrina, Noor Zainura Zainon, Abu Hassan Mohd Ariffin, Olsson Gustaf. Application of membrane bioreactor technology in treating high strength industrial wastewater: a performance review. Desalination 2012;305(1):1-11.

[20] Williams Mark D, Ravindran Varadarajan, Pirbazari Massoud. Modeling and process evaluation of membrane bioreactor for removing biodegradable organic matter from water. Chem Eng Sci 2012;84(24):494-511.

[21] Berning Torsten, Shakhshir Saher Al. Applying hot wire anemometry to directly measure the water balance in a proton exchange membrane fuel cell - Part 1: Theory. Int J Hydrogen Energy 2015;40(36):12400-12. 
[22] Badruzzaman Mohammad, Oppenheimer Joan A, Jacangelo Joseph G. Impact of environmental conditions on the suitability of microconstituents as markers for determining nutrient loading from reclaimed water. Water Res 2013;47(16):6198-210.

[23] Cui Lihua, Ouyang Ying. Removal of nutrients from septic tank effluent with baffle subsurface-flow constructed wetlands. J Environ Manag 2015;153(4):33-9.

[24] Zhang J, Wang Q. Sustainable mechanisms of biochar derived from brewers' spent grain and sewage sludge for ammonia-nitrogen capture. J Clean Prod 2016;112:3927-34.
[25] Samsó Roger, García Joan. Bacteria distribution and dynamics in constructed wetlands based on modelling results. Sci Total Environ 2013;461-462(1):430-40.

[26] Shangguan Haidong, Liu Junzhuo. Start-up of a spiral periphyton bioreactor (SPR) for removal of COD and the characteristics of the associated microbial community. Bioresour Technol 2015;193(10):456-62.

[27] Bajaj Swati, Singh Dileep K. Biodegradation of persistent organic pollutants in soil, water and pristine sites by coldadapted microorganisms: mini review. Int Biodeterior Biodegrad 2015;100(5):98-105. 